\title{
Analysis of working capital management of industry practices in Indonesia
}

\author{
Lukas Purwoto \& Caecilia Wahyu Estining Rahayu \\ University of Sanata Dharma, Yogjakarta, Indonesia
}

\begin{abstract}
Managers need to pay more attention to the efficiency in working capital management in order to maintain the long term viability of the growth. This research focuses on the working capital management practices in Indonesia companies. This study aims to reveal the in-depth description of working capital management among industries of Indonesian public companies. There are several analysis used in the study, such as univariate analysis, comparative analysis, and graphical analysis. This research shows that Indonesia's public companies generally have positive working capital needs. This study also points out the significant differences in the measures of working capital management across many different industries. The result is expected to give contributions to the development of the literature and company management in Indonesia.

Keywords: efficiency, working capital management, longterm viability
\end{abstract}

\section{INTRODUCTION}

Working capital management of a company requires optimal treatment in terms of accounts receivable, inventory, and accounts payable. In managing working capital, the manager needs to properly allocate the fund and achieve high efficiency so as to contribute to the company's value enhancement (Bolek et al. 2012). Because the level of short term assets and current liabilities reflect the company's business aspects in daily activities, working capital management becomes crucial short term decision for many companies.

Recently, international research from KoralunBereznicka (2014) found out that a company's working capital is influenced most by national factors, and less by industry factors. That research argued about the importance of noticing that there are differences of working capital needs across industries in a certain country. Meanwhile, a more practical view from Morgan (2015) suggested that a company should always check and monitor its working capital metrics by analyzing them based on their position on the industry in order to improve the working capital management. Based on the results of those data analysis, a company manager can consider and take planned and calculated actions.
These are the research questions: first, what are the descriptions of working capital management measures of the public companies in Indonesia? Second, is there any significant difference among the industry groups within those working capital management measures?

The objective of this research is to obtain a more comprehensive description about the working capital management among industries consisting of public companies in Indonesia during the most recent period, year 2015 and 2016. This research topic is in the same field as research area which had been done by Margaretha \& Oktaviani (2016) and Syarief \& Wilujeng (2009) who analyzed public companies. However, the objective of and the methodology used in this research are different from the previous researches. This research also uses the more recent data period, more company samples, as well as more types of measures of the working capital management being analyzed.

\section{LITERATURE REVIEW AND RESEARCH HYPOTHESIS}

Many literatures had explained how working capital management is applied in a company (i.e: Preve \& 
Sarria-Allende 2010, Ross et al. 2013). A company often begins a cycle by buying raw materials using the open account purchase method, which resulted in accounts payable. This cash payment is not made immediately but paid in the future (accounts payable periods/days for payables). The raw materials are then processed into finished products that can be sold. The period of time between the initial purchase date of an inventory up to the sale date of an inventory is called the inventory conversion period (or just inventory period). Next, a company may sell its inventory on credit to create account receivable. The difference of days between cash receipt time from the consumer and credit sale time is called accounts receivable period (or also called days for receivables). Thus, the time length between the cash payment has made by a company when buying raw materials and the cash payment receipt from sales to consumers is known as the cash conversion cycle.

Although cash conversion cycle has provided good measures for the researchers studying working capital management, some of the researchers use net trade cycle. Shin \& Soenen (1998) argued that cash conversion cycle is an addition concept, which unfortunately does not equally apply to each of the components (that is: accounts receivable period, inventory, and accounts payable) because the items used as the divisor are not from the same type. They believe that net trade cycle is basically the same as cash conversion cycle, which expresses all of its three components as sale percentages. Thus, net trade cycle actually indicates the amount of "days sales" which have to be funded by a company working capital. Recently, Silva (2011) applied net trade cycle indicators in investigating working capital management efficiency in a manufacture company in Portugal. Thus, the two cycles may be perceived as measures which compliment each other in order to understand the working capital management of a company.

By using multinational companies in the United States as samples, Costa (2014) focused on the comparison between the cash conversion cycle of flight and consumer goods industries. Sabunwala et al. (2013) compared the working capital management of automobile, cement and steel industries in India's public companies. Based on the data pertaining 157 public companies on the stock market of Karachi Pakistan on 2009, Bhutto et al. (2011) researched about the cash conversion cycle on 12 industry groups. Anova test result shows that there are differences among the average cash conversion cycle among the 12 industry groups. The research performed by Bhutto et al. also found that oil and gas industry have a cash conversion cycle that is longer than the other industries. However, unfortunately, the research only used a data period of one year and only focused on one measure of working capital management.

Panigrahi \& Chaudhury (2015) discussed is the existence of a case in which a company has a negative working capital, and then described that negative working capital does not always mean poor company financial condition. Similarly, Costa (2014) showed that, on certain years, the negative average value of the cash conversion cycle and its three components are found in the industry that he investigated. Although only a few companies have negative cash conversion cycle, most companies understandably have positive cycles (Ross et al. 2013). Theoretically, company cash conversion cycle will increase when the period of inventory and account receivable are longer. On the contrary, cash conversion cycle will decrease if the company delays the payment of accounts payable and thus prolongs the period of accounts payable. Based on these descriptions, the following research hypothesis is proposed:

$\mathrm{H} 1$ : The working capital management measures (i.e.: net trade cycle, cash conversion cycle, accounts receivable period, inventory period, and accounts payable period) on Indonesia's public companies are significantly positive.

The size and composition of a working capital may vary widely among industries due to the characteristic differences of the industries (Atrill 2009). One manufacture business may invest so much in inventory, while service companies have less goods inventory in their stores and warehouses. Some types of business may have common habbit in doing credit trade while other businesses do it less. There is also a possibility that companies within the same industry imitate each other, showing a "herd behavior", when setting working capital policies (Damodaran 2001). This behavior is not odd when the managers are investing in company working capital by basing it on reference groups. Advanced research hypothesis is as follow: $\mathrm{H} 2$ : There are significant differences in the working capital management measures (i.e.: net trade cycle, cash conversion cycle, accounts receivable period, inventory period, and accounts payable period) found among groups of industries in Indonesia's public companies.

\section{RESEARCH METHOD}

This research uses 2015 and 2016 financial report data from public companies listed in Indonesia Stock Exchange. The companies which become sample candidates are non-financial companies in industries with adequate numbers. This research obtained 284 company samples, each observed for two years, and 
thus performed 568 observations. Company samples come from 22 industries based on sub-sector categories on two digits' codes (Fact Book 2014, Indonesia Stock Exchange). The overall statistics of company samples shows that, in average, the companies have been operating for 32 years. This research studies not just companies reporting positive profits in their income statements (around 72 percent), some of the investigated companies even have negative net income period (around 28 percent).

This research performs its analysis by applying various analytic techniques. Firstly, it uses graphic and table analyses. The second technique is univariate analysis, while the third is comparative analysis on sample groups. Analysis is run with the help of computer program called Stata, the same program used by Hamilton (2013). In general, this research calculates all research variables based on previous studies. The following are the calculation of each research variables:

Net trade cycle (cash trade cycle, NTC):

$N T C=($ Accounts $\operatorname{Re}$ ceivable + Inventory -

AccountPla yablePeriod) $x \frac{365}{\text { sales }}$

Cash conversion cycle (CCC):

$C C C=($ Account $\operatorname{Re}$ ceivable + InventoryPeriod $)-$

AccountPla yablePeriod

Accounts receivable period (ARP):

ARP $=\frac{\text { Account } \operatorname{Re} \text { ceivable }}{\frac{\text { Sales }}{365}}$

Inventory period (IP):

$$
I P=\frac{\text { Inventory }}{\frac{\text { CostofGoodsSold }}{365}}
$$

Accounts payable period (APP):

$$
A P P=\frac{\text { Accounts Payable }}{\frac{\text { CostofGoodsSold }}{365}}
$$

where $c_{a}=$ interface adhesion; $\delta=$ friction angle at interface; and $k_{1}=$ shear stiffness number.

\section{RESULT AND DISCUSSION}

This research presents a number of industries which only have a little company data or observation. It does not really support the fulfillment of normality assumption and the wellness of the parametric method procedures performed. The result of ShapiroWilk normality test on each industry group of each research variable shows that normality assumption may not be fulfilled by some industries (i.e. property and real estate industry and plantation industry). Thus, analysis is mainly based on statistical measures which enable the use of non-parametric methods. Several previous researches like the one by Seeger et al. (2011) also analyzes working capital management research data using median instead of mean as the base.

To what extent does working capital management applied by Indonesia's public companies? Figure 1 displays the median of cash conversion cycle (CCC) of the 22 industries. The median for most industries are positive, except for telecommunication industry which is negative. The median which appear long belongs to the property and real estate, chemicals, and metal and allied products industries. While the median which appear short belongs to the telecommunication, restaurant, hotel and tourism, and building construction industries. Visually, this graphic shows variability in the length of cash conversion cycle across industries, which are caused especially by the negativity of the telecommunication industry and the lengthy median belonging to the property and real estate industry. Figure 2 shows the median of net trade cycle (NTC) among 22 industry classifications. Visually, the graphic shows pattern similarities between net trade cycle (NTC) and cash conversion cycle (CCC).

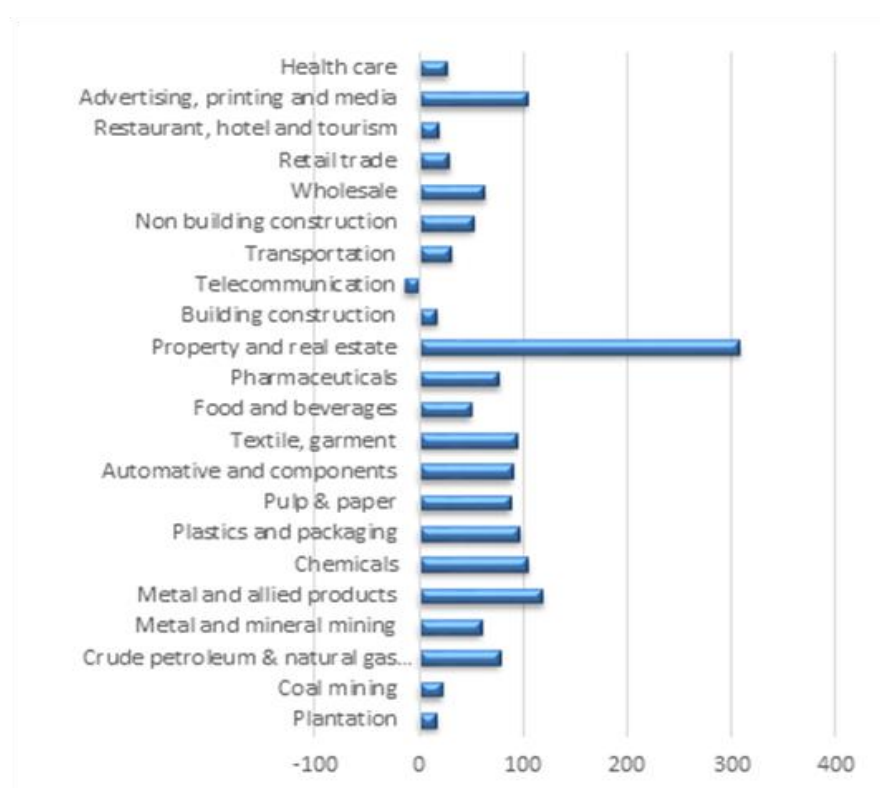

Figure 1. Cash conversion cycle (days). 
Furthermore, Table 1 shows various statistics related to $\mathrm{H} 1$ hypothesis testing for all firm year observations. Both the median and the average of accounts payable period (APP), inventory period (IP), accounts receivable period (ARP), cash conversion cycle (CCC), and net trade cycle are positive and more than 0 day. Chi-square one-sample tests (Ha: median $>0$ ) resulted in a very small $p$ value of less than 0.01 .

Meanwhile, $t$ test $(\mathrm{Ha}$ : mean $>0)$ also resulted in a very small $\mathrm{p}$ value of less than 0.01 . The test results, of both the one using non-parametric method and parametric method, lead to conclusions which support H1.

Therefore, net trade cycle, cash conversion cycle, accounts receivable period, inventory period, and accounts payable period are significantly positive on overall observation.

Table 1. Chi-square one-sample tests and t tests.

\begin{tabular}{llllll}
\hline & APP & IP & ARP & CCC & NTC \\
\hline Obs & 568 & 568 & 568 & 568 & 568 \\
Median & 40.0 & 62.3 & 38.8 & 62.5 & 58.9 \\
\#positive & 556 & 536 & 558 & 476 & 502 \\
\#negative & 0 & 0 & 0 & 89 & 63 \\
\#zero & 12 & 32 & 10 & 3 & 3 \\
p value (Ha: & 0.00 & 0.00 & 0.00 & 0.00 & 0.00 \\
Median > 0) & & & & & \\
Mean & 66.8 & 392.1 & 51.4 & 376.6 & 141.1 \\
$\begin{array}{l}\text { Std.Dev . } \\
\text { t stat }\end{array}$ & 115.4 & 2519.3 & 49.3 & 2440.5 & 674.2 \\
p value (Ha: & 13.8 & 3.7 & 24.8 & 3.7 & 4.9 \\
mean > 0) & 0.00 & 0.00 & 0.00 & 0.00 & 0.00 \\
& & & & &
\end{tabular}

This part continues the test statistically by comparing the working capital management measures in all of 22 industries. Table 2 shows the printout summary of the Kruskal-Wallis and ANOVA tests results. The table provides chi-squared statistical value from Kruskal-Wallis Test, as a non-parametric method, along with its p-value. Kruskal-Wallis Test resulted in a very small p-value of less than 0.05 for each variable. Such result leads to the conclusion that there is a significant difference among industries. Furthermore, the analysis of variance (ANO$\mathrm{VA}$ ) provides a more popular parametric method to test the difference of some averages. ANOVA test result ( $p$-value less than 0.01 ) also agrees with the previous Kruskal-Wallis finding about significant difference across industries.

Table 2. Kruskal-Willis tests and ANOVA.

\begin{tabular}{llllll}
\hline & APP & IP & ARP & CCC & NTC \\
\hline Chi-squared & 45.05 & 229.99 & 146.49 & 176.16 & 177.64 \\
Prob. & 0.00 & 0.00 & 0.00 & 0.00 & 0.00 \\
F & 1.72 & 2.26 & 6.63 & 2.26 & 3.60 \\
Prob. > F & 0.02 & 0.00 & 0.00 & 0.00 & 0.00 \\
\hline
\end{tabular}

\section{CONCLUSIONS}

The research results provide statistical descriptions and the results of the tests on working capital management measures on Indonesia's companies. This research shows that Indonesia's public companies generally have positive working capital needs. Only companies in the telecommunication industry have the tendency to have negative working capital needs. Therefore, the companies generally need to find and manage the best resources in order to fulfill this short-term finance needs.

This study also points out the significant differences in the measures of working capital management across many different industries. These differences may be caused by policies and general practice following industry's terms on inventory management system or credit trade management system. Company managers need to pay attention to the comparison between the size of working capital management and its changes and the industry itself to monitor their company's health.

\section{REFERENCES}

Atril, P. 2009. Financial management for decision makers. Boston: Prentice Hall.

Bhutto, N.A., Abbas, G., Mujeeb-ur-Rehman, \& Shah, S.M. 2011. Relationship of cash conversion cycle with firm size, working capital approaches and firm's profitability: a case of Pakistani industries. Pak. j. eng. technol. sci. 1: 45-64.

Bolek, M., Kacprzyk, M. \& Wolski, R. 2012. The relationship between economic value added and cash conversion cycle in listed on the WSE. Financial Internet Quarterly 8: 110.

Costa, B.R. 2014. Cash conversion cycle across industries. Working paper from NOVA - School of Business and Economics.

Damodaran, A. 2001. Corporate finance: theory and practice. John Wiley \& Sons, Inc.

Hamilton, L.C. 2013. Statistics with Stata: updated for version 12. Cengage Learning.

Koralun-Bereźnicka, J. 2014. On the relative importance of corporate working capital determinants: findings from the EU countries. Contemporary Economics 8: 415-434.

Seeger, S., Locker, A. \& Jergen, C. 2011. Working capital management in the Swiss chemical industry. Journal of Business Chemistry 8(2): 87-98.

Margaretha, F. \& Oktaviani C. 2016. Pengaruh manajemen modal kerja terhadap profitabilitas pada usaha kecil dan menengah di Indonesia. Jurnal Bisnis dan Akuntansi 18: $11-24$.

Morgan, J.P. 2015. Optimizing cash flow: how to manage working capital. Commercial Banking: 1-5.

Panigrahi, A.K. \& Chaudhury, S.K. 2015. Negative working capital and business sustainability (a case study of Nestle India Limited. Journal of Business Management, Commerce \& Research 4: 35-43.

Preve, LA. \& Sarria-Allende, V. 2010. Working capital management. Oxford: Oxford University Press, Inc. 
Ross, S.A., Westerfield, R.W. \& Jordan, B.D. 2013. Fundamentals of corporate finance. New Jersey: McGraw-Hill Companies, Inc.

Sabunwala, Z.Z., Vyas, M., \& Wangal, K.A. 2013. Working Capital Management - Best Practices Adopted across Multiple Industries. IBMRD's Journal of Management and Research 2: 248-255.

Shin, H. \& Soenen, L. 1998. Efficiency of working capital and corporate profitability, Financial Practice and Education 8: 37-45.

Silva, S.M. 2012. Effects of working capital management on the profitability of Portuguese manufactoring firms. (unpublished thesis). Universidade do Minho.

Syarief, M.E. \& Wilujeng, I.T. 2009. Cash conversion cycle dan hubungannya dengan ukuran perusahaan, profitabilitas dan manajemen modal kerja. Jurnal Ekonomi Bisnis 14: 6169. 